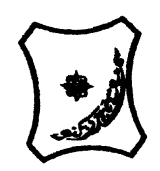

Bayero Journal of Pure and Applied Sciences, 14(1):130 - 141

Received: March, 2021

Accepted: April, 2021

ISSN 2006 - 6996

\title{
HEALTH RISK ASSESSMENT OF HEAVY METALS FROM PESTICIDES USE IN PLATEAU STATE, NIGERIA
}

\author{
${ }^{1}$ Bawa, U., ${ }^{2}$ Ahmad,A., ${ }^{2}$ Ahmad, J.N. and ${ }^{2}$ Ezra, A. G. \\ ${ }^{1}$ Department of Biological Sciences, Bayero University, Kano, P.M.B. 3011, Kano, Nigeria \\ ${ }^{2}$ Department of Applied Ecology, Abubakar Tafawa Balewa University, P.M.B. 0248, Bauchi, Nigeria \\ E-mail:ubawa.bio@buk.edu.ng
}

\begin{abstract}
Heavy metals bioaccumulation in agricultural crops fumigated with pesticides has grown into a major concern globally. This study assessed heavy metals concentrations (Cd, Pb, $\mathrm{Cr}, \mathrm{Cu}, \mathrm{Zn}$ ) in commonly consumed crops and their corresponding soil from agricultural farm lands in Jos Plateau State, Nigeria. The mean concentrations of heavy metals in the studied crops ranged from 0.17-100.75, 0.17-54.33, 0.83-28.75, 0.17-5.50, 0.5-0.5 $\mathrm{mg} / \mathrm{kg}$ for $\mathrm{Zn}, \mathrm{Pb}, \mathrm{Cu}, \mathrm{Cr}$, and Cd respectively. The trend of heavy metals in the crops were in decreasing order of $\mathrm{Zn}>\mathrm{Pb}>\mathrm{Cu}>\mathrm{Cr}>\mathrm{Cd}$ and their concentrations varied in different parts of the crops. The mean concentration of $\mathrm{Cd}, \mathrm{Pb}$, and $\mathrm{Cr}$ in the studied crops were above the WHO, (2019) permissible limits and therefore a call for concern. The mean concentrations of heavy metals in the soil varied from 0.5-0.5, 2.50-13.83, 3.67-5.75, 11.83-26.33, and 41-89.50 mg/kg for Cd, $\mathrm{Pb}, \mathrm{Cr}, \mathrm{Cu}$ and $\mathrm{Zn}$ respectively and were below the UNEP, (2013) permissible limits for agricultural soil. The result showed that Pb had the highest transfer factor (1.91) in (Capsicum annuum) and Zn had the least. Similarly, the result revealed high Pollution index value for Pb compared to other metals. Hazard quotient and Hazard index of all the crops were less than 1; thus the consumption of these crops is unlikely to pose health risks to the target population. However, the result showed health risk from daily intake of some of the studied crops for Pb ((Brassica oleracea, Lactucasativus, Zea mays, Spinaciaoleracea, and Capsicum annuum). Hence, regular monitoring and screening of pesticides for heavy metals should be employed by government agencies.
\end{abstract}

Key words: Bioaccumulation factor, Heavy metals, Hazard Quotient, Pesticides

\section{INTRODUCTION}

Intensification of agricultural activities around the world to meet the ever growing food demand has led to an increase in the use of pesticides particularly in Northern Nigeria. Even though pesticides are beneficial to agricultural production but uncontrolled use can be detrimental, many users especially in northern Nigeria are inadequately informed about potential short and long term risk of pesticides in the environment. According to world Health Organization (WHO), 20\% of pesticides are used in the developing countries and the trends of pesticides use is increasing (WHO, 2000). Nigeria has been ranked first among West African countries importing pesticides from the United Kingdom (Okafoagul, et al., 2017). However, despite the significant contribution of pesticides to agricultural production, evidences have shown that they could cause detrimental potential health risk to humans and the ecosystem as well (Lou et al., 2009). The use of agro-chemicals such as herbicides, fungicides and insecticides play an important role in the contamination of agricultural crops and the subsequent transfer along food chain to humans (Zhong et al., 2017).

Studies have shown the presence of heavy metals in pesticides (Yuguda, et al., 2015; Kabata-Pendias and Pendias, 1992; Barau et al., 2018). Therefore, continuous and uncontrolled application of these agrochemicals and can potentially exacerbate the accumulation of heavy metals in the agricultural soils over time (Wang et al., 2004). Despite the ban of heavy metals in pesticides in developed countries, study by Defarge et al., (2018) have revealed for the first time the presence of $\mathrm{As}, \mathrm{Co}, \mathrm{Cr}, \mathrm{Ni}, \mathrm{Pb}$ as contaminants in 22 pesticides formulations at levels above admissible ones in water at their recommended dilutions rate in Europe. 
BAJOPAS Volume 14 Number 1,June, 2021

This trend is worrisome in developing countries particularly in Africa as majority of the pesticides infiltrating the markets have been shown to contain heavy metals (Yaguda, et al., 2015; Barau et al., 2018). Even though most studies have studied and attributed heavy metals sources in food crops from waste-water irrigation, industrial waste and contaminated waste disposal site. Sources of heavy metals from pesticides in food crops/vegetables and their health hazard in humans should not be overlooked. More so, there are limited information on the heavy metals concentration in food crops from pesticides and their health risk in Northern Nigeria. Hence, this study was designed with the aim of determining the concentration of heavy metals $(\mathrm{Cd}, \mathrm{Pb}, \mathrm{Cr}, \mathrm{Cu}$, $\mathrm{Zn}$ ) from pesticides in the root, stem, leaf and fruit of some crops, and the respective farmland soil in Jos and their associated human health risk.

\section{MATERIALS AND METHODS}

Samples of leaves, stems, roots and fruits of nine selected matured plants were collected by randomly picking from two farm lands. Five (5) replicates from each of the nine (9) plants were collected from Naraguta Farm (A) in Plateau State at coordinates of N09 58.586 , E008 53.820 and Naraguta Farm (B) at coordinates of $\mathrm{N} 09^{0} 58.562$, E008 53.230 . At each sampling sites, $20 \mathrm{~g}$ each of the nine crops namelytomatoes, pepper, onions, cabbage, carrot, cucumber, spinach, lettuce and maize) were collected from three different locations in each farm land to provide replicate samples of each crop. Samples were collected from the roots, stems, leaves and fruits of each of these crops and their corresponding soil. The crops and soil samples were collected in a clean brown paper envelope, labelled and stored at Abubakar Tafawa Balewa University (ATBU) Biology laboratory.

\section{Preparation of Samples}

The uneatable portions of the plants were separated from edible portion and chopped into small pieces. The samples were oven dried at $80^{\circ} \mathrm{C}$ and crushed using a stainless steel blender and passed through a $2 \mathrm{~mm}$ sieve at Biology laboratory ATBU. The resulting fine powder were kept at room temperature before analysis. The soil samples were air dried in the laboratory, crushed and passed through a $2 \mathrm{~mm}$ mesh size sieve and stored at room temperature before analysis.

\section{Heavy Metal Analysis}

The non-edible portions of the plants were separated from edible portion and chopped into small pieces. The soil and plant samples were oven dried at $80^{\circ} \mathrm{C}$ and $1 \mathrm{~g}$ each was digested separately with a mixture of (Nitric acid) $\mathrm{HNO}_{3}$, $65 \%$ (Per chloric acid) $\mathrm{HClO}_{4}$ and $70 \%$ (Sulfuric) $\mathrm{H}_{2} \mathrm{SO}_{4}$ in 5:1:1 ratio). The samples were analyzed for heavy metals using an Atomic Absorption Spectrophotometer model 210 VGP as described by (Zhong et al., 2018).

\section{Health Risk Assessment}

\section{Daily intake of metal}

The daily intake of metals(DIM) was calculated to determine the health risk from consuming vegetables, with trace of heavy metals concentration using the formula below as described by (Zhonget al., 2017). DIM $=\frac{M \times K \times I}{W}$

\section{Hazard Quotient}

The health risks to the local inhabitants from the consumption of vegetables were evaluated based on the Hazard Quotient, which is the ratio between exposure and oral reference dose $\left(R_{f} D\right)$ as described (US-EPA, 2013). Given as; $\mathrm{HQ}=\frac{\mathrm{Dim}}{R f D}$

\section{Hazard Index}

Potential risk to human health due to more than one heavy metal known as the Hazard index (HI) was calculated as described by US-EPA, (2013), which is the total sum of all the Hazard Quotients as shown in the equation below:

$\mathrm{HI}=\Sigma \mathrm{HQ}=\mathrm{HQ}_{\mathrm{Cd}}+\mathrm{HQ}_{\mathrm{Pb}}+\mathrm{HQ}_{\mathrm{Cr}}+\mathrm{HQ}_{\mathrm{Cu}}+\mathrm{HQ}_{\mathrm{Zn}}$

\section{Estimated daily Intake (EDI)}

The degree of toxicity of heavy metals to human upon their daily intake $(\mathrm{mg} / \mathrm{kg} /$ day $)$ known as the estimated daily intake was computed for each element as described by US-EPA, (2013). $\mathrm{EDI}=\frac{\text { Cmetal } \times \text { Averagedailyintake }}{B A} \mathrm{mg} / \mathrm{kg} /$ day

\section{Pollution Index (PI)}

Pollution index (PI) is the ratio of metal concentration in a biotic or abiotic medium to that of the regulatory Standard of international bodies such as United states Environmental Protection Agency (USEPA) was computed as described by (Chukwuma, 1994).

Mathematically, PI was computed as $\mathrm{PI}=\mathrm{C}$ plant/C US-EPA-STANDARD

\section{Statistical Analysis}

Analysis of variance ANOVA was used to analyze data using statistical software "R" 2014 version as described by Dytham, (2011).

\section{RESULTS}

\section{Heavy metals concentration in crops}

The concentration of heavy metals in different parts of crops (root, stem, leaf, and fruit) from the study area is given (Table 1.).

The concentrations of heavy metals ranged from 0.17-100.75 mg/kg, 0.17-54.33, 0.83-28.75, 0.17-5.50, 0.5-0.5 mg/kg for $\mathrm{Zn}, \mathrm{Pb}, \mathrm{Cu}, \mathrm{Cr}$, and Cd respectively. 
BAJOPAS Volume 14 Number 1,June, 2021

The result revealed that there was significant variation $(p<0.05)$ in the concentration of heavy metals in different parts the studied crops (Table 1 ). The trend of heavy metals in the studied crops was in decreasing order of $\mathrm{Zn}>\mathrm{Pb}>\mathrm{Cu}>\mathrm{Cr}>\mathrm{Cd}$. The mean concentrations of $\mathrm{Cd}, \mathrm{Pb}$, and $\mathrm{Cr}$ were above the WHO, (2019) in most of the investigated crops, while the concentrations of $\mathrm{Cu}$ and $\mathrm{Zn}$ were below the WHO, (2019) permissible limits (Table 1).

Heavy metals concentration in soil

The mean concentration of heavy metals in the corresponding soils of the crops under investigation ranged from $0.5-0.5,2.50-13.83$, $3.67-5.75,11.83-26.33$, and $41-89.50 \mathrm{mg} / \mathrm{kg}$ for $\mathrm{Cd}, \mathrm{Pb}, \mathrm{Cr}, \mathrm{Cu}$ and $\mathrm{Zn}$ respectively (Table 2.). The concentration of cadmium was not detected in all the corresponding soils of the studied crops except in the soils of Carrot (Daucuscarota) and Lettuce (Lactucasativus). The mean concentration of heavy metals in the corresponding soils of all the studied crops was below the permissible set by UNEP, (2013) and NESREA, (2011) for agricultural soils (Table 2). Analysis of variance (ANOVA) revealed a significant difference in heavy metals concentration in the corresponding soils of most studied crops, however the concentration of chromium in the soils of all the studied crops showed no significant difference except between the soil of carrot (Daucuscarota) $\mathrm{P}<0.05$ (Table 2).

Transfer factor of metals from soil to crops The result for heavy metals transfer factor in crops from the study area is given in Table 3. The Bioaccumulation factor (BAF) for crops grown in the study area ranges from 0.19-1.91, 0.25-0.82, 0.23-0.82, 0.08-0.76 for $\mathrm{Pb}, \mathrm{Cr}, \mathrm{Cu}$, $\mathrm{Zn}$ respectively. While BAF was not computed for $\mathrm{Cd}$ in all the studied crops. BAF was highest for pepper (Capsicum annuum) (1.91), followed by maize (Zea mays) (0.95), tomato (Solanumlycopersicum) (0.93), Spinach (Spinaciaoleracea (0.82) and cabbage (Brassica oleracea (0.76) (Table 3.). Zinc BAF was lowest for all the investigated crops compared to other metals and $\mathrm{Pb}$ showed the highest BAF than other metals.

\section{Pollution indices}

The result of the computed pollution indices (PI) in the edible parts of crops grown in the study area is given in Table 4. The PI value ranges from 2.5-2.5, 0.56-20.00, 0.29-1.59, 0.02-0.34, and 0.19-0.43 for $\mathrm{Cd}, \mathrm{Pb}, \mathrm{Cr}, \mathrm{Cu}$, and $\mathrm{Zn}$ respectively. Pollution indices were not detected in the edible parts of all the studied crops for Cadmium, except in lettuce (Lactucasativus) and Onion ( Allium cepa).Pollution indices value were higher for $\mathrm{Pb}$ in all the studied crops compared to other metals. PI was highest 20.00 in pepper (Capsicum annuum), followed by lettuce (Lactucasativus) 18.89, cabbage (Brassica oleracea) 13.89, maize (Zea mays) 12.22, Spinach (Spinaciaoleracea) 10.83. The high PI values greater than 1 indicates that these crops are contaminated and are therefore consider unsafe for human consumption. The trend of pollution indices in the edible parts of the studied crops was in the order of $\mathrm{Pb}>\mathrm{Cd}>\mathrm{Cr}>\mathrm{Zn}>\mathrm{Cu}$.

\section{Health risk assessment}

\section{Estimated daily intake of metal (EDI)}

The result of the estimated daily intake of metals for adults (average age 60 years), are presented in Table 5. The result showed that the values of daily intake for $\mathrm{Pb}$ through the consumption some of the studied the crops (Brassica oleracea) (0.00597),(Lactucasativus ) (0.00812), (Zea mays) (0.00526), Spinaciaoleracea (0.00466), Capsicum annuum $(0.00860)$ had exceeded the oral reference dose (the daily exposure of individual to toxins or pollutants that can pose no appreciable hazard over life time) and are likely to cause human health risk. The estimated daily intake for $\mathrm{Cd}$, $\mathrm{Cr}, \mathrm{Cu}$, and $\mathrm{Zn}$ through the consumption of all the studied crops were below the oral reference dose (RFD) and are therefore considered safe for consumption (Table 5).

\section{Estimated Hazard Quotient (HQ) and Hazard index (HI)}

The result of the estimated hazard quotient and hazard index through the consumption of the studied crops are presented in Table 6 . The estimated hazard quotient values for all the investigated crops ranged from $0.0602-0.0602$, 0.00508-0.18275, 5.41E-05-0.00029, 0.00254$0.04112,0.00081-0.01046$, for $\mathrm{Cd}, \mathrm{Pb}, \mathrm{Cr}, \mathrm{Cu}$, and $\mathrm{Zn}$ respectively. The result revealed that $\mathrm{HQ}$ value was highest (0.18275) in Capsicum annuum and least (5.41E-05) in (Daucuscarota). The HQ values of all the studied crops are the following order of health risk $\mathrm{Pb}(0.18275)>\mathrm{Cd}$ $\begin{array}{lll}(0.0602)>\mathrm{Cu} & (0.04112)>\mathrm{Zn} & (0.01046)>\quad \mathrm{Cr}\end{array}$ (0.00029). 
BAJOPAS Volume 14 Number 1,June, 2021

Table 1. Mean Concentrations of Heavy Metals (Mg/Kg) in Crops Grown in Jos (2017) Name of Sample Botanical Name Hausa Name Heavy metals

\begin{tabular}{|c|c|c|c|c|c|c|c|}
\hline 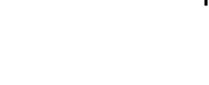 & & 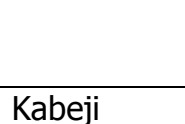 & \multicolumn{5}{|c|}{$\mathrm{mg} / \mathrm{kg}$} \\
\hline Root & & & ND & $5.67 \mathrm{~b}$ & $1.92 a$ & $2.50 a$ & $18.00 a$ \\
\hline Leaf & & & ND & 4.17ab & $3.67 \mathrm{~b}$ & $8.67 b$ & $11.50 a$ \\
\hline Carrot & Daucuscarota & Karas & & & & & \\
\hline Leaf & & & ND & 4.50ab & $2.67 \mathrm{~b}$ & $7.67 \mathrm{~b}$ & $19.50 a$ \\
\hline Taproot & & & ND & $2.17 a$ & $0.67 a$ & $4.67 a$ & $17.00 a$ \\
\hline Cucumber & Cucumissativus & Kokwamba & & & & & \\
\hline Root & & & ND & $0.67 a$ & 2.00ab & $11.17 \mathrm{~b}$ & $4.00 \mathrm{~b}$ \\
\hline Stem & & & ND & $3.33 b$ & $1.58 \mathrm{a}$ & $5.33 a$ & $32.00 d$ \\
\hline Leaf & & & ND & $1.67 a b$ & $1.50 a$ & $8.50 \mathrm{ab}$ & $0.67 a$ \\
\hline Stem & & & $0.5 a$ & $3.00 a$ & $3.00 \mathrm{~b}$ & $4.75 a$ & $12.67 \mathrm{~b}$ \\
\hline Leaf & & & $0.5 a$ & $5.67 a$ & $1.25 a$ & $7.33 a$ & $14.25 b$ \\
\hline Maize & Zea mays & Masara & & & & & \\
\hline Root & & & ND & $54.33 b$ & $4.67 c$ & $15.33 b$ & 32.33ab \\
\hline Stem & & & ND & $5.33 a$ & $0.17 a$ & $7.83 a$ & $41.33 b$ \\
\hline Leaf & & & ND & $4.50 a$ & $1.50 \mathrm{~b}$ & $7.00 a$ & $25.00 \mathrm{a}$ \\
\hline Fruit & & & ND & $3.67 a$ & $1.75 b$ & $4.25 a$ & $18.50 \mathrm{a}$ \\
\hline WHO (2019) & & & 0.2 & 0.3 & 2.3 & 40 & 60 \\
\hline
\end{tabular}

Limits: FAO/WHO(2019)

Mean followed with same letter across the column are not significantly different $p>0.05$ using Duncan test

$\mathrm{N}=6$ replicates 
BAJOPAS Volume 14 Number 1,June, 2021

Table 1. Contd.

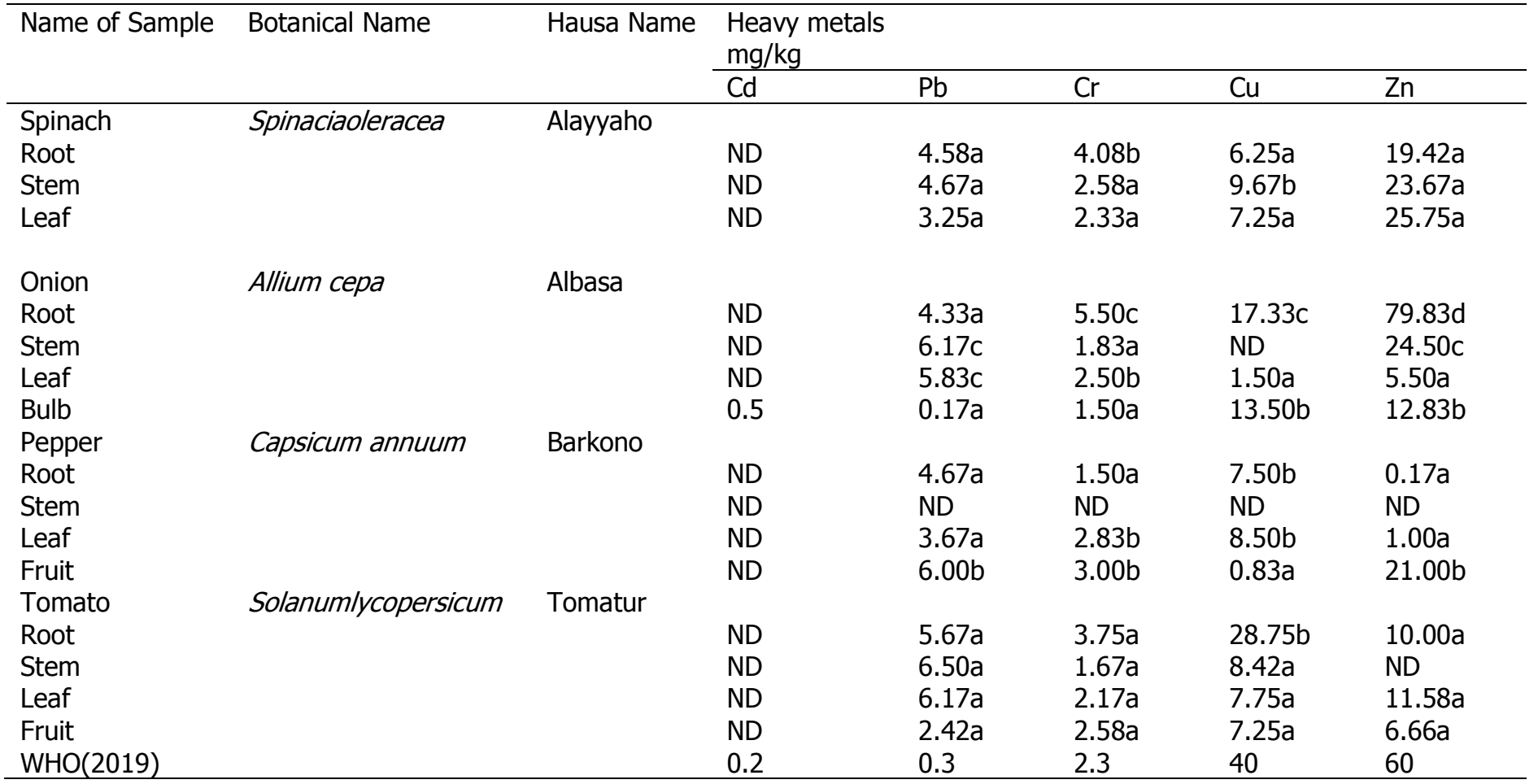

Limits FAO/WHO (2019)

Mean followed with same letter across the column are not significantly different $p>0.05$ using Duncan test

$\mathrm{N}=6$ replicates 
BAJOPAS Volume 14 Number 1,June, 2021

Table 2. Mean Concentrations of Heavy Metals $(\mathrm{Mg} / \mathrm{Kg}$ ) in Soils of Corresponding Crops Grown in Jos (2017) Soil from the land of Botanical Name Hausa Name Heavy metals

\begin{tabular}{|c|c|c|c|c|c|c|c|}
\hline & & & \multicolumn{5}{|c|}{$\mathrm{mg} / \mathrm{kg}$} \\
\hline & & & $\mathrm{Cd}$ & $\mathrm{Pb}$ & $\mathrm{Cr}$ & $\mathrm{Cu}$ & $\mathrm{Zn}$ \\
\hline Cabbage & Brassica oleracea & Kabeji & ND & $8.50 a$ & $3.75 a$ & $11.83 a$ & $83.58 b$ \\
\hline Carrot & Daucuscarota & Karas & 0.5 & $4.00 a$ & $5.75 b$ & $26.33 d$ & $63.25 a b$ \\
\hline Cucumber & Cucumissativus & Kokwamba & ND & $11.00 \mathrm{ab}$ & $3.83 a$ & 18.92abcd & 68.17ab \\
\hline Lettuce & Lactuca sativa & Salad & 0.5 & $9.17 a b$ & $4.25 a$ & $21.33 \mathrm{bcd}$ & 70.58ab \\
\hline Maize & Zea mays & Masara & ND & $13.83 b$ & $5.08 a$ & $19.67 \mathrm{~cd}$ & $89.50 b$ \\
\hline Spinach & Spinaciaoleracea & Alayyaho & ND & 7.33ab & 3.67a & $17.25 a b c$ & $50.25 a b$ \\
\hline Onion & Allium cepa & Albasa & ND & 7.50ab & $3.67 a$ & 16.33abc & $41.67 a$ \\
\hline Pepper & Capsicum annuum & Barkono & ND & $2.50 a$ & $4.00 a$ & $21.67 \mathrm{bcd}$ & 78.83ab \\
\hline Tomato & Solanumlycopersicum & Tomatur & ND & 5.58ab & $3.92 a$ & 15.92ab & $60.50 a b$ \\
\hline UNEP, (2013) & & & 10 & 200 & 200 & 50 & 250 \\
\hline NESREA & & & 3 & NIL & 100 & 100 & NIL \\
\hline
\end{tabular}

Limits:UNEP, 2013

Mean followed with same letter across the column are not significantly different $p>0.05$ using Duncan test $\mathrm{N}=6$ replicates

Table 3. Bioaccumulation Factor (BAF) of Heavy Metals in the Edible Parts of Crops Grown in Jos (2017)

Name of Sample Botanical Name Hausa Name BAF

\begin{tabular}{|c|c|c|c|c|c|c|c|}
\hline \multirow{2}{*}{ 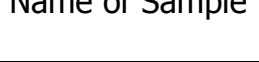 } & \multirow{2}{*}{ 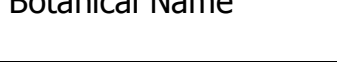 } & \multirow{2}{*}{ (2) } & \\
\hline & & & $\mathrm{Cd}$ & $\mathrm{Pb}$ & $\mathrm{Cr}$ & $\mathrm{Cu}$ & $\mathrm{Zn}$ \\
\hline Cabbage & Brassica oleracea & Kabeji & ND & 0.45 & 0.60 & 0.48 & 0.76 \\
\hline Carrot & Daucuscarota & Karas & ND & 0.58 & 0.25 & 0.23 & 0.29 \\
\hline Cucumber & Cucumissativus & Kokwamba & ND & 0.19 & 0.53 & 0.40 & 0.22 \\
\hline Lettuce & Lactuca sativa & Salad & ND & 0.56 & 0.56 & 0.31 & 0.08 \\
\hline Maize & Zea mays & Masara & ND & 0.95 & 0.50 & 0.36 & 0.33 \\
\hline Spinach & Spinaciaoleracea & Alayyaho & ND & 0.57 & 0.82 & 0.45 & 0.46 \\
\hline Onion & Allium cepa & Albasa & ND & 0.55 & 0.77 & 0.49 & 0.74 \\
\hline Pepper & Capsicum annuum & Barkono & ND & 1.91 & 0.61 & 0.26 & 0.09 \\
\hline Tomato & Solanum/ycopersicum & Tomatur & ND & 0.93 & 0.65 & 0.82 & 0.16 \\
\hline
\end{tabular}

BAF value greater than $>1$ is indicating high uptake of metal 
BAJOPAS Volume 14 Number 1,June, 2021

Table 4. Pollution Indices of Heavy Metals in the Edible Parts of Crops Grown in Jos (2017)

\begin{tabular}{lllllllll}
\hline Sampling Site & Name of Sample & Botanical Name & Hausa Name & \multicolumn{2}{l}{$\begin{array}{l}\text { Pollution } \\
\text { index }\end{array}$} & & & \\
\cline { 5 - 8 } & & & & Cd & $\mathrm{Pb}$ & $\mathrm{Cr}$ & $\mathrm{Cu}$ & $\mathrm{Zn}$ \\
\hline Jos & Cabbage & Brassica oleracea & Kabeji & 00 & 13.89 & 1.59 & 0.22 & 0.19 \\
& Carrot & Daucuscarota & Karas & 00 & 7.22 & 0.29 & 0.12 & 0.28 \\
& Cucumber & Cucumissativus & Kokwamba & 00 & 9.44 & 1.30 & 0.13 & 0.39 \\
& Lettuce & Lactuca sativa & Salad & 2.5 & 18.89 & 0.54 & 0.18 & 0.24 \\
& Maize & Zea mays & Masara & 00 & 12.22 & 0.76 & 0.11 & 0.31 \\
& Spinach & Spinaciaoleracea & Alayyaho & 00 & 10.83 & 1.01 & 0.18 & 0.43 \\
& Onion & Allium cepa & Albasa & 2.5 & 0.56 & 0.65 & 0.34 & 0.21 \\
& Pepper & Capsicum annuum & Barkono & 00 & 20.00 & 1.30 & 0.02 & 0.35 \\
& Tomato & Solanumlycopersicum & Tomatur & 00 & 8.06 & 1.12 & 0.18 & 0.03 \\
\hline
\end{tabular}

N.B PI value greater than $>1$ is indicating high pollution load

Table 5. Estimated Daily Intake of Metals (EDI) (Mg/Kg/Bw/Day) Through Consumption of Crops Grown in Jos (2017)

\begin{tabular}{lllllll}
\hline Botanical Name & Hausa Name & $\begin{array}{l}\text { Estimated } \\
\text { daily intake }\end{array}$ & & & & \\
\cline { 3 - 7 } & & $\mathrm{Cd}$ & $\mathrm{Pb}$ & $\mathrm{Cr}$ & $\mathrm{Cu}$ & $\mathrm{Zn}$ \\
\hline Brassica oleracea & Kabeji & $\mathrm{ND}$ & 0.00597 & 0.00526 & 0.01242 & 0.01648 \\
Daucuscarota & Karas & $\mathrm{ND}$ & 0.00311 & 0.00096 & 0.00669 & 0.02437 \\
Cucumissativus & Kokwamba & $\mathrm{ND}$ & 0.00406 & 0.00430 & 0.00753 & 0.03344 \\
Lactuca sativa & Salad & 0.0007 & 0.00812 & 0.00179 & 0.01051 & 0.02043 \\
Zea mays & Masara & $\mathrm{ND}$ & 0.00526 & 0.00251 & 0.00609 & 0.02652 \\
Spinaciaoleracea & Alayyaho & $\mathrm{ND}$ & 0.00466 & 0.00334 & 0.01039 & 0.03691 \\
Allium cepa & Albasa & 0.0007 & 0.00024 & 0.00215 & 0.01935 & 0.01839 \\
Capsicum annuum & Barkono & $\mathrm{ND}$ & 0.00860 & 0.00430 & 0.00119 & 0.03010 \\
Solanumlycopersicum & Tomatur & ND & 0.00346 & 0.00370 & 0.01039 & 0.00287 \\
RfD & & 0.001 & 0.004 & 1.5 & 0.04 & 0.30 \\
\hline
\end{tabular}

RFD: USEPA, (2013)

Table 6. Estimated Hazard Quotient and Hazard Index for Adult Population through the Consumption of Crops Grown in Jos (2017)

\begin{tabular}{|c|c|c|c|c|c|c|c|c|}
\hline \multirow[t]{2}{*}{$\begin{array}{l}\text { Name of } \\
\text { Sample }\end{array}$} & \multirow[t]{2}{*}{ Botanical Name } & \multirow[t]{2}{*}{$\begin{array}{l}\text { Hausa } \\
\text { Name }\end{array}$} & \multicolumn{5}{|c|}{$\begin{array}{l}\text { Hazard } \\
\text { Quotient(HQ) }\end{array}$} & \multirow[t]{2}{*}{$\begin{array}{l}\text { Hazard } \\
\text { Index(HI) }\end{array}$} \\
\hline & & & $\mathrm{Cd}$ & $\mathrm{Pb}$ & $\mathrm{Cr}$ & $\mathrm{Cu}$ & $\mathrm{Zn}$ & \\
\hline Cabbage & Brassica oleracea & Kabeji & ND & 0.12691 & 0.00029 & 0.02640 & 0.00467 & 0.15828 \\
\hline Carrot & Daucuscarota & Karas & ND & 0.06599 & $\begin{array}{l}5.41 \mathrm{E}- \\
05\end{array}$ & 0.01421 & 0.00690 & 0.08716 \\
\hline Cucumber & Cucumissativus & Kokwamba & ND & 0.08630 & 0.00024 & 0.01599 & 0.00948 & 0.11201 \\
\hline Lettuce & Lactuca sativa & Salad & 0.0609 & 0.17260 & 0.00010 & 0.02234 & 0.00579 & 0.26174 \\
\hline Maize & Zea mays & Masara & ND & 0.11168 & 0.00014 & 0.01294 & 0.00751 & 0.13228 \\
\hline Spinach & Spinaciaoleracea & Alayyaho & ND & 0.09899 & 0.00019 & 0.02208 & 0.01046 & 0.13172 \\
\hline Onion & Allium cepa & Albasa & 0.0609 & 0.00508 & 0.00012 & 0.04112 & 0.00521 & 0.11245 \\
\hline Pepper & Capsicum annuum & Barkono & ND & 0.18275 & 0.00024 & 0.00254 & 0.00853 & 0.19406 \\
\hline Tomato & Solanumlycopersicum & Tomatur & ND & 0.07361 & 0.00021 & 0.02208 & 0.00081 & 0.09671 \\
\hline
\end{tabular}

\section{DISCUSSION}

In this study, the concentrations of heavy metals in the investigated crops fumigated with pesticides ranged from $0.17-100.75,0.17$ $54.33,0.83-28.75,0.17-5.50,0.5-0.5 \mathrm{mg} / \mathrm{kg}$ for $\mathrm{Zn}, \mathrm{Pb}, \mathrm{Cu}, \mathrm{Cr}$, and $\mathrm{Cd}$ respectively. The present study indicated that most of the investigated crops had exceeded the WHO, (2019) permissible limits for $\mathrm{Cd}, \mathrm{Pb}$ and $\mathrm{Cr}$, while the concentration of $\mathrm{Zn}$ and $\mathrm{Cu}$ in the studied crops were below WHO permissible limits. The result revealed that there were significant variation $(p<0.05)$ in the concentration of heavy metals in different parts of the studied crops, with no clear trend. 
BAJOPAS Volume 14 Number 1,June, 2021

The mean $\mathrm{Zn}$ content in the studied crops (0.17$100.75 \mathrm{mg} / \mathrm{kg}$ ) was significantly higher compared to $(19.36-37.76 \mathrm{mg} / \mathrm{kg}$ ) reported for crops irrigated with waste water in Pakistan (Mahmood and Malik, 2014), and $(1.88 \mathrm{mg} / \mathrm{kg}$ ) Zn content in crops from Saudi Arabia (Balkhair and Ashraf, 2016). The mean concentration in this study $(0.17-100.75 \mathrm{mg} / \mathrm{kg})$ was similar to the $\mathrm{Zn}$ concentration reported in Indonesia $(5.12-90.69 \mathrm{mg} / \mathrm{kg})$ from waste water irrigation (Siaka et al.,2014) and (32.01-69.26 mg/kg) Zn concentration in vegetables from Beijing, China (Liu et al., 2005).

The mean concentration of $\mathrm{Pb}$ in the investigated crops $(0.17-54.33 \mathrm{mg} / \mathrm{kg})$ was higher compared to $(0.23-0.64 \mathrm{mg} / \mathrm{kg})$ in India from crops irrigated with waste water (Kulkarni 2017), and in China $(1.82 \mathrm{mg} / \mathrm{kg})$ in vegetables collected from market (Hongwen, et al., 2017). The $\mathrm{Pb}$ concentration in this study was also higher compared to $(0.26-0.54 \mathrm{mg} / \mathrm{kg})$ in Ethiopia (Eliku and Leta, 2017) and (1.42-2.76 $\mathrm{mg} / \mathrm{kg}$ ) in Pakistan (Khannum, et al., 2017) in crops irrigated with waste-water.

The mean concentration of $\mathrm{Cu}$ in this study varied from $(0.83-28.75 \mathrm{mg} / \mathrm{kg})$ was comparatively higher than $(0.56 \mathrm{mg} / \mathrm{kg})$ in Saudi Arabia (Balkhair and Ashraf, 2016), and (1.1-2.3 $\mathrm{mg} / \mathrm{kg}$ ) in India (Kulkarni et al., 2017). However, $\mathrm{Cu}$ contents in this study were significantly lower than $(4.34-150.5 \mathrm{mg} / \mathrm{kg}$ ) in Indonesia (Siakaet al., 2014) and (12.6-82.1 mg/kg) in Nigeria (Oti, 2015).

The mean level of $\mathrm{Cr}(0.17-5.50 \mathrm{mg} / \mathrm{kg})$ in crops in this study were significantly higher than $(0.16-0.32 \mathrm{mg} / \mathrm{kg}$ ) reported in India (Kulkarni et al., 2017), and higher than (0.37-0.60 mg/kg) in Pakistan (Khannum, et al., 2017). However, the $\mathrm{Cr}$ contents in this study was similar to the result $(0.84-2.4 \mathrm{mg} / \mathrm{kg})$ obtained by Iwuanyanwu and Chioma, (2017) in Nigeria and within the range of (0.51-1.73) reported in Ethiopia (Eliku and Leta, 2017).

The mean concentrations of $\mathrm{Cd}(0.5-0.5 \mathrm{mg} / \mathrm{kg})$ reported only in (Lactuca sativa) in this study was comparatively similar to $(0.30-0.62 \mathrm{mg} / \mathrm{kg})$ reported in India (Kulkarni et al., 2017), and also $(0.6 \mathrm{mg} / \mathrm{kg})$ obtained in China by (Hongwen, et al., 2017). The mean Cr concentrations in the present study was also significantly lower than the result obtained in China (0.1-900 mg/kg) (Zhong et al., (2014) and also less than $(0.10-12.4 \mathrm{mg} / \mathrm{kg})$ reported in Nigeria by (Oti, 2015).

Results of this study indicate that the accumulation of certain metals $\mathrm{Cd}, \mathrm{Pb}, \mathrm{Cr}$ above the permissible limits is a serious health risk for human population. $\mathrm{Cd}$ have been shown to hinders sulfhydryl enzymes and interacts with other cell ligands, disrupting oxidative phosphorylation pathways (Jomova and Valko, 2011; Waisberg et al., 2003). It accumulates in the human bones, lungs, liver, kidneys, and nerve tissues, leading to their damage and malfunction (Tsutsumiet al., 2014). It affects the respiratory system and enhances the development of kidney stones (Hambach, 2013). Exposure of $\mathrm{Cd}$ to the liver induces hepatocellular injuries to humans through the synthesis of metallothionein (Kang et al., 2013).Cadmium also interferes with transport across cell membranes and epithelia which eventually affect cell function and homeostasis (Van Kerhove et al., 2010). This study has shown that the concentration of heavy metals in crops fumigated with pesticides as the only source of metal contamination are equal or several folds higher than metals contents in crops reported from other sources like waste water irrigation, mine sites, and hence sources of heavy metals from pesticides should not be overlooked.

The mean concentration of heavy metals in the corresponding soils of the crops under investigation ranged from $0.5-0.5,2.50-13.83$, 3.67-5.75, $11.83-26.33$, and $41-89.50 \mathrm{mg} / \mathrm{kg}$ for $\mathrm{Cd}, \mathrm{Pb}, \mathrm{Cr}, \mathrm{Cu}$ and $\mathrm{Zn}$ respectively. The mean concentration of heavy metals in the corresponding soils of all the studied crops was below the permissible set by UNEP, (2013) and NESREA, (2011) for agricultural soils. This could be due to the higher uptake of heavy metals by the crops. The mean soil concentration of $\mathrm{Cd}$ in this study, were lower than the soil concentration of $0.93 \mathrm{mg} / \mathrm{kg}$ reported in Ethiopia (Eliku and Leta, 2017) and substantially lower compared to $(126 \mathrm{mg} / \mathrm{kg})$ in Nigeria ((Oti, 2015).Lead $(\mathrm{Pb})$ concentration in soil were also lower compared to $(70.36 \mathrm{mg} / \mathrm{kg}$ ) in China (Liu et al., (2013) and higher than $(2.31 \mathrm{mg} / \mathrm{kg})$ in India (Kumar et al., 2017). While the soil concentration of $\mathrm{Cu}$ and $\mathrm{Zn}$ in the present study were both similar to $30.3 \mathrm{mg} / \mathrm{kg}, 88.5 \mathrm{mg} / \mathrm{g}$ for $\mathrm{Cu}, \mathrm{Zn}$ obtained in Ethiopia (Eliku and Leta, 2017).

In this study bioaccumulation factor (BAF) varied significantly in different crops and the trend of metal transfer (BAF) from soil to crops were in the order of $\mathrm{Pb}>\mathrm{Cr}>\mathrm{Cu}>\mathrm{Zn}$ which were similar to the result reported by Kumar, et al, (2017) Chotanagpur in India, and in Ehiopia by (Gebreyohannes and Gebrekidan, 2018). The $\mathrm{BCF}$ for $\mathrm{Cr}$ in this study were lower compared with (1.82) reported in Saudi Arabia by Balkhair and Ashraf (2016) and higher than (0.16) in green pepper in Ethiopia by (Eliku and Leta, 2017). Kumar et al. (2017) also reported closely similar (1.03) for $\mathrm{Cu}$ in India in comparison to 
BAJOPAS Volume 14 Number 1,June, 2021

BAF obtained in this study. Most of the crops under investigation showed higher metals concentration in their corresponding soil than plant tissues, and hence this could be responsible for the transfer of the heavy metals to their edible parts. The variation in the BAF in different crops were due to the metal concentration in the soil, bioavailability of metals, their chemical forms, difference in uptake capability and growth rate of different plant species and heavy metal contents in pesticides (Singh et al., 2010).

The result showed that the values of daily intake for $\mathrm{Pb}$ through the daily adult consumption of the studied crops (Brassica oleracea) (0.00597), (Lactucasativus) (0.00812), (Zea mays) (0.00526), Spinaciaoleracea (0.00466), Capsicum annuum (0.00860) had exceeded the oral reference dose and are likely to cause severe human health risk. This could be attributed to the use of lead based pesticides indiscriminately by farmers in the study area. Study by Defargeet al., (2018), Barauetal., (2018), Yagudaet al., (2005) have revealed the presence of heavy metals in pesticides. Lead has been shown to interrupt enzyme activation, inhibit trace mineral absorption, stop structural protein synthesis by binding to sulfhydryl protein, and lower the availability and levels of sulfhydryl antioxidant reserves in the body (Ercal et al., 2001; Patrick (2006). Lead also has been linked to incidence of neurological disorders, hypertension and cognitive impairment(Patrick2006).

The potential health risk through the consumption of the metal contaminated crops was calculated using the hazard quotient (HQ). The result of this study indicated that the adult consumption of all the studied crops are unlikely to pose health risk to human as the HQ values was less than 1 for all heavy metals. In this study, the estimated hazard index shown that the consumption of all the investigated crops for all metals will not pose health risk to human as

\section{REFERENCES}

Ahmad, J.U.,Goni, M.A. (2010). Heavy metal contamination in water, soil, and vegetables of Industrial areas in Dhaka, Bangladesh. Environ. Monit. Assess, 166: 347-357.

Arora, M., Kiran, B., Rani, S., Kaur, A., Mittal, N. (2008) Heavy metal accumulation in vegetables Irrigated with water from different sources. Food. Chem.11 (4):811-815.

Amini, M, Khademi, H., Afyuni, M., Abbaspour, K.C. (2005). Variability of available cadmium In relation to soil properties the $\mathrm{HI}<1$. Lower $\mathrm{HQ}$ and $\mathrm{HI}<1$ have been reported in India by Kumar et al., (2017), in Ethiopia by Eliku and Leta, (2017) and Gebreyohannes and Gebrekidan (2018). Higher $(>1) \mathrm{HQ}$ and $\mathrm{HI}$ values were also reported in different crops by Barauet al., (2018) and Patrick and Chioma (2017) in Nigeria.

\section{CONCLUSION}

The present study revealed that most of the agricultural crops fumigated with pesticides were enriched with metals $\mathrm{Cd}, \mathrm{Pb}$, and $\mathrm{Cr}$ at concentrations above the WHO permissible limits. While the concentration of $\mathrm{Zn}$ and $\mathrm{Cu}$ in all the studied crops were below the WHO permissible limits. The mean concentration of heavy metals in the corresponding soils of all the studied crops was below the permissible set by UNEP(2013) and NESREA (2011) for agricultural soils. Heavy metals concentrations varied in different parts of the plants and in their corresponding soil. The Bioaccumulation factor shown higher $(>1)$ for $\mathrm{Pb}$ only in Capsicum annuum (1.91) indicating low retention rate of the metal in the soil. The estimated daily intake revealed that the daily adult consumption of some crops Brassica oleracea (0.00597), Lactucasativus (0.00812), Zea mays (0.00526), Spinaciaoleracea (0.00466), Capsicum annuum $(0.00860)$ had exceeded the oral reference dose (RFD). This shown that the daily intake of these crops contaminated with heavy metals from pesticides in the study area could pose potential health risk to human. However, the estimated hazard quotient (HQ) and hazard index (HI) in this study were lower $(<) 1$ in all the studied crops and therefore unlikely to posed health risk through the consumption of these crops. Regular monitoring and screening of pesticides for heavy metals contents should be employed by concerned authorities.

Conflict of interest

The authors declare that they do not have conflict of interest.

and landuse in an arid region in central Iran. Water Air Soil Pollution, 162:205218.

Aktaruzzaman, M., Fakhruddin, A.N.M., Chowdhury, M.A.Z., Fardous, Z., Alam, M.K. (2013).

Accumulation of heavy metals in soil and their leafy vegetables in the Region of DhakaAricha Highway, Savar, Bangladesh, Pakistan, Journal of Biological Science 16(7):332-338.

Barau, B.W., Abdulhamed, A., Ezra, A.G., Muhammed, M., Bawa, U., Yuguda, A.U., Kyari, E.M. (2018). Heavy metal 
BAJOPAS Volume 14 Number 1,June, 2021

contamination of some vegetables from pesticides and potential Health risk in Bauchi, Northern Nigeria, International Journal of science and technologyol.7(1).

California Environmental Protection Agency of Environmental Health Hazard Assessment (2011). Chemicals known to the state to cause cancer or reproductive toxicity,

http://oehha.ca.gov/prop65/prop65 list/files/p6 5single090211.pdf

Cui, Y.J., Zhu, Y.G., Zhai, R.H., Huang, Y., Qiu, Y., Liang, J.(2005). Exposure to metal Mixtures and human health impacts in a contaminated area in Nanning, China. Environ. Int. 31:784-790.

Chen, Y., Wu, P., Shao, Y., Ying, Y. (2014). Health risk assessment of heavy metals in vegetables grown around battery production area. ScientiaAgricola, 71, 126-132.

Chary, N.S., Kamala, C.T., Raj, D.S.S. (2008). Assessing risk of heavy metals from consuming food grown on sewage irrigated soils and food chain transfer, Ecotoxicology Environment Safety 69(3) 513-524.

Chukwuma, S.C. (1994). Evaluating Baseline Data for lead $(\mathrm{Pb})$ and cadmium $(\mathrm{Cd})$ in Rice, Yam, Cassava, and Guinea Grass from cultivated soils in Nigeria, Toxicological and environmental Chemistry, Vol.45pp.45-56.

Cobb, G.P., Sands, K., Waters, M., Wixson, B.G., Dorward-King, E. (2000). Accumulation of Heavy metals by vegetables grown in mine waste, Environmental Toxicology Chemistry.19(3), 600-607

Datta, A, Sanyal, S., Saha, S. (2001). A study on natural and synthetic humic acids and their Complexing ability towards cadmium. Plant Soil 235(1):115-125.

Defarge, N., Spiroux de Vendomois, J., Seralini, G.E. (2018). Toxicity of formulants and heavy metals in glyphosphate-based herbicides and other pesticides, Toxicology Reports, 5:156-163.

Dytham, C. (2011). Chosing and using statistics, $a$ biologist guide. $3^{\text {rd }}$ ed:WileyBlackwell.Eugenia, G., Vicente, A., Rafeal, B. (1996). Heavy metals incidence in the application of inorganic fertilizers Pesticides to rice farming soils, Environmental Pollution, Vol. 92:1, pp:19-25.

Ercal, N., Gurer-Orhan, H., Aykin- Burns, N. (2001). Toxic metals and oxidative stress part I:Mechanism involved in metal -induced oxidative damage. Cur Top Med Chem 1:529-539

Eckel, H., Roth, D., Dohler, H., Schultheis, U. (2008). Assessment and reduction of heavy metals Input into agroecosystem. In P.Schlegel, S. Durosoy, and A.W., Jongbloed (Eds.), TraceElements in animal production systems. The Netherlands: WageningenAcademic,3343.

Garg, V.K., Yadav, P., Mor, S. B., Pulhani, V. (2014). Heavy metals bio concentration fromSoil to vegetables and assessment of health risk caused by their ingestion, Biological Trace Element Resourses,157:256-265,

Gupta, N., Khan, D.K., Santra, S.C. (2008). An assessment of heavy metal contamination inVegetables grown in wastewater -irrigated areas of Titagarh West Bengal, India. Bulletin Of Environmental Contamination and Toxicology, 80,:115-118.

Guala, S.D., Vega, F.A., Covelo, E.F.(2010). Heavy metal concentration in plants and different Harvestable parts; A soil- plant equilibrium model. Environmental pollution 158: 2659-2663.

Gimeno-Gracia, E., Andreu, V., Boluda, R.(1996). Heavy metals incidence in the application of Inorganic fertilizers and pesticides to rice farming soils, Environmental Pollution,92:19-25.

Gebreyohannes, F., Gebrekidan, A. (2018). Health risk assessment of heavy metals through Consumption of spinach vegetable grown in Elalla River, Bull.Chem. Soc. Ethiop.32,(1), 65-75.

Goel, S., Malik, J.A., Nayyar, H. (2009). Molecular approach for phytoremediation of metal Contaminated sites. Archives of agronomy and Soil Science 55(4):451-475.

Hart, A.D., Azubuike, C.U., Barimalaa, I.S., Achinewhu, S.C. (2015). Vegetable consumption Pattern of households in selected areas of the old Rivers state in Nigeria, African Journal of Food Agriculture and Nutritional Development (AJFAND): Vol. 5:(1).

Hambach, R. (2013). Co- exposure to lead increases the renal response to low levels of cadmium Metallurgy workers. Toxicol. Lett 22.

Hongwen Dai, Xiuxian Song, Baifei Huang (2017). Health risk assessment of heavy metals via Consumption of vegetables collected from vegetables markets in 
BAJOPAS Volume 14 Number 1,June, 2021 Hengyang, China RevistaDela faculted de ingenieriavol:(32) (5) :95-102.

Jolly, Y.N., Islam, A., Shawkat, A. (2013). Transfer of metals from soil to vegetables and Possible health risk assessment, Springer Plus, 2(1):1-8.

Jomova, K, Valko, M. (2011). Advances in metalinduced oxidative stress and human disease. Toxicology 283:65-87.

Kang, M.Y., Cho, S.H., Lim, Y.H., Seo, J.C., Hong, Y.C. (2013). Effects of environmental Cadmium exposure on liver function in adults, Occ. Environ. Med. 70:268-273.

Khanum, K., Baqar, M., Qadir, A., Mumtaz, M., Tahir, A., Jamil, N., Mahmood, A. (2017)

Heavy metal toxicity and human health risk surveillances of wastewater irrigated Vegetables in Lahore Distric, Pakistan, Carpathian Journal of Earth and Environmental Sciences: 12, (2), 403412.

Kabata-pendias, A., Pendias, H. (1992). Trace element in soils and plants. $2^{\text {nd }}$ Edition. CRC press. Inc. Boca Raton, Fl. 365.

Alkhair, K.S., and Ashraf, M. A. (2016). Field accumulation risks of heavy metals in soil and vegetables crop irrigated with sewage water in western region of Saudi Arabia, Saudi Journal of Biological Sciences, 23, S32-S44.

Kumar, A., Manas, D., Ruplal, P., (2017). Concentration of trace metals and potential health risk Assessment via consumption of food crops in the south Chotanagpur of Jharkhand, India, Pharmal Innovation Journal6:(9):159167.

Kulkarni, C.P. (2017). Assessment of heavy metals in vegetables and cereals collected from local Market, Mumbai, International Journal of food science and nutrition, Vol 4,(6):71-74.

Liu, W.H., Zhao, J.Z., Ouyang, Z.Y., Soderlund, L., Liu, G.H. (2005). Impacts of sewage irrigation On heavy metals distribution and contamination, Environment International, 31: 805-812.

Luo, C.L., Shen, Z.G., Lou, L.Q., Li, X.D. (2006). EDDS and EDTA-enhanced phytoextraction of Metals from artificially contaminated soil and residual effects of chalant compounds, Environmental pollution .144:862-871.

Mahmood, A., Malik, R.N. (2014). Human health risk assessment of heavy metals through consumption of contaminated vegetables collected from different irrigation sources in Lahore, Pakistan, Arabian Journal of Chemistry:7, 91-99.

Nicholson, F.A., Smith, S.R., Alloway, B.J., Carlton-smith, C., Chambers, B.J. (2003). An Inventory of heavy metals inputs to agricultural soils in England and Wales. Science of The Total Environment, 311, 205-219.

Oti, W.J.O. (2015). Pollution Indices and Bioaccumulation Factors of Heavy Metals in Selected Fruits and vegetables from a Derelict Mine and their associated Health implications, International Journal of Environmental Science and Toxicology Research,Vol.3(1):9-15.

Osu, C.I., Ogoko, E.C. (2014). Bioconcentration and transfer of heavy metal from soil into Verniniaamydaglina, Telferaoccidendalis, and Amaranthusspinosus. Journal of Applied Phytotechnology in Environmental Sanitation. 3(4):117-121.

Okafoagu, N.C., Oche, M.O., Lawal, N. (2017). Pesticide use among farmers in Sokoto, North Western Nigeria: A Descriptive study, International Journal of Tropical Disease and Health (24) (3):1-8.

Patrick-Iwuanyanwu, K., Chioma, N.C. (2017). Evaluation of heavy metals content and human Health risk assessment through consumption of vegetables from selected markets in Bayelsa State, Nigeria. Biochem 6:332. doi: 10.4172/2161-1009.1000332

Patrick, L. (2006). Lead toxicity part II: the role of free radical damage and the use of antioxidants In the pathology and treatment of lead toxicity. Altern. Med Rev 11:114-127.

Stafilov, T., Sajn, R., Pan Cevski, Z., Boev, B., Frontasyeva, M.V., Strelkova, L.P.(2010). Heavy Metal contamination of topsoials around a lead and Zinc smelter in the Republic of Macedonia, Journal of Hazardous Material. 175:896914.

Stasinos, S., Zabetakis, I. (2013). The uptake of nickel and chromium from irrigation water by Potatoes, carrots and onions. Ecotoxicol. Environment, 91:122-128.

Siaka, I.M., Utama, I.M.S., Manuaba, I.P., Adnyana, I.M. (2014). Heavy metals contents in the edible parts of some vegetables grown in CandiKuning, Bali and their predicted Pollution in the cultivated soil. Journal of Environment and Earth Science 4,23:78-83.

Singh, A., Sharma, R.K., Agrawal, M., Marshall, F.M. (2010). Health risk assessment of 
BAJOPAS Volume 14 Number 1,June, 2021

heavy Metals via dietary intake of foodstuffs from wastewater irrigated site of a dry tropical area of India, Food Chem. Toxicol. 48(2), 611-619.

Smith, S.R. (2009). A critical review of the bioavailability and impacts of heavy metals in Municipal solid waste composts compared to sewage sludge. Environ. Int. 35(1):142-156.

Suciu, I., Cosma, C., Todica, M., Bolboaca, S.D, Jantchi, L.(2008). Analysis of Soil heavy metal pollution and pattern in central Transylvania, International Journal of molecular Science, vol.9:434-453

Eliku,T., and Leta, S. (2017). Heavy metals bioconcentration from soil to vegetables and appraisal of health risk in koka and Wonji farms, Ethiopia, Environmental Science and Pollution Research, 24(12), 11807-11815.

Tsutsumi, T., Ishihara, A., Yamamoto, A., Asaji, H., Yamakawas, S., Tokumura, A. (2014). The Potential protective role of lysophospholipid mediators in nephrotoxicity induced by Chronically exposed cadmium. Food chem. Toxicol 65:52-62.

US- EPA, (2013). Reference dose (RFD): Description and use in health risk assessments, background document $1 \mathrm{~A}$, Integrated risk information system (IRIS). United States Environmental Protection Agency, Washington, DC. Accessed on $9^{\text {th }}$ June, 2021 .<http://www epa.gov/iris/lfd.htm>.

U.S Department of Health and Human Services (2005). Public Health Service Agency for Toxic Substances and Disease Registry, Toxicological profile for nickel, p 32.
UNEP, (2013). Environmental risk challenges of anthropogenic metals flows and cycles, in: E. Vandervoet, R. Salminen, $M$. Eckelman, G., Mudd, T., Norgate, R., Hischier (Eds.), A report of the working Group on the Global Metal Flow to the international Resource Panel, P.231.

Van Kerkhove, E., Pennemans, V., Swennen, Q. (2010). Cadmium and transport of ions and Substances across cell membranes and epithelia, Biometals 23:823-855.

Waisberg, M., Joseph, P., Hale, B., Bayersmann, D. (2003). Molecular and cellular mechanisms Cadmium carcinogenesis. Toxicology 192: 95-117.

Wang, Y., Fang, J., Leonard, S.S., Krishma, Rao, K.M. (2004). Cadmium inhibits the electron Transfer chain and induce reactive oxygen species. Free Radical Biol. Med 36:1434-1443.

FAO/WHO Codex Alimentarius International Food Standards (2019). General standard for contaminants and toxins in food and feed, 193-1995. Accessed on $9^{\text {th }}$ June, 2021.

http://www.fao.org/faowhocodexalimentarius/en/.

Yuguda, A.U., Abubakar, Z.A., Jibo, A.U., AbdulHameed, A., Nayaya, A.J. (2015). Assessment of Toxicity of Some Agricultural pesticides on Earthworm (Lumbriscus Terrestris). American Eurasian Journal of sustainable Agriculture. 9(4):49-59.

Zhong, T., Dawei, X., Limin, Z., Xiuying, Z. (2017). Concentration of heavy metals in vegetables and potential health risk assessment in China, Environmetal Geochem Health.40(1),313-322. 